\title{
Live-In Dalam Mengembangkan Pendidikan Lingkungan Di Desa Bara Kecamatan Air Buaya Kabupaten Buru-Maluku
}

\author{
Nurlaila Sopamena $^{1 *}$, Janaba Renggiwur ${ }^{1}$, Nur Apriyani Nukuhaly ${ }^{1}$ \\ ${ }^{1}$ Dosen FITK IAIN Ambon \\ *E-mail: nurlailasopamena@iainambon.ac.id
}

\begin{abstract}
Abstrak: Berdasarkan analisis situasi masyarakat di Desa Bara maka masalah mendasar yang dihadapi oleh masyarakat adalah rendahnya Sumber Daya Manusia dan minimnya pengetahuan dan keterampilan masyarakat tentang pendidikan lingkungan dan pengelolaan lahan. Masyarakat hanya mengandalkan tanaman umur panjang saja seperti tanaman kelapa dan coklat. Tanaman kelapa dilakukan setiap dua sampai tiga kali dalam setahun, sedangkan panen tanaman coklat dilakukan setiap tahun setelah lima tahun penanaman. Berdasarkan hasil kegiatan yang telah dilakukan oleh masyarakat di Desa bara Kecamatan Air Buaya Kabupaten Buru Propinsi Maluku maka dapat disimpulkan bahwa kegiatan tersebut sangat bermaanfat bagi masyarakat setempat guna mempersiapkan mereka menjadi masyarakat sadar lingkungan dan berkarya karena memiliki pengetahuan dan keterampilan yang memadahi dan hasilnya dapat dijadikan sumber penghasilan tambahan bagi masyarakat itu sendiri guna memenuhi kebutuhan keluarga.
\end{abstract}

\section{Kata Kunci: Pengabdian, Cinta Lingkungan, Pemenuhan Kebutuhan}

Abstract: Based on the analysis of the community situation in Bara Village, the basic problems faced by the community are the low human resources and the lack of community knowledge and skills regarding environmental education and land management. The community only relies on longevity plants such as coconut and cocoa. Coconut plants are carried out every two to three times a year, while harvesting of cocoa is done every year after five years of planting. Based on the results of the activities carried out by the community in Bara village, Air Buaya, Buru district, Maluku province, it can be concluded that these activities are very useful for the local community to prepare them to become environmentally aware and work because they have adequate knowledge and skills and the results can be used as sources additional income for the community itself to meet family needs.

Keywords: Devotion, Love the Environment, Fulfillment of Needs 
Desa Bara merupakan salah satu desa di kecamatan Air Buaya Kabupaten Buru Propinsi Maluku. Desa ini berjarak sekitar 125 km dari kota Namlea ibukota Kabupaten Buru. Untuk menjangkau desa tersebut dapat ditempuh dengan menggunakan jalur lintas darat ataupun jalur lintas laut dengan menggunakan speedboat. Sedangkan lama perjalanan ke Kota Namlea dari Kota Ambon memakan waktu \pm 8 jam perjalanan menggunakan kapal fery.

Penduduk Desa Bara sangat majemuk, dimana terdiri dari suku Sula, Ternate, Ambon, Buton, dan Jawa. Mayoritas penduduknya beragama muslim yang terbagi dalam RT, dan total kepala keluarga sebanyak $\pm 130 \mathrm{KK}$. Kondisi tempat tinggal penduduk sebagian besar sudah semi permanen walaupun masih tergolong rumah sederhana. Penduduk Desa Bara sudah tiga kali melakukan perpindahan mukim dikarenakan adanya bencana alam dan konflik. Sumber air yang ada di desa tersebut belum dapat dialirkan ke rumah-masing-masing, tetapi masyarakat dapat mengambil air di tempat penampungan umum yang ada. Itulah satu-satunya sumber air yang ada di dusun tersebut.

Tingkat pendidikan masyarakat di Desa Bara kebanyakan adalah tamatan SD, SMP, dan SMA. Pada saat tim melakukan pengabdian masyarakat, \pm sekitar 9 orang yang alumni universitas dari berbagai kampus di Maluku. Dengan tingkat pendidikan yang rendah dan keterampilan yang tidak memadai, maka warga Desa Bara sulit untuk mendapatkan pekerjaan yang layak.

Berdasarkan hasil pengukuran dengan Kepala Desa Bara Bapak Sulaiman Tabona pada tanggal 29 September 2014 lokasi Desa Bara terletak di dataran rendah dengan ketinggian $0-8$ meter diatas permukaan laut dan luas pemukiman $289.374 \mathrm{~m}^{2}$. Hanya $30 \%$ wilayah yang digunakan untuk pemukiman penduduk dan sisanya dijadikan lahan bertani oleh warga setempat. Mayoritas pekerjaan masyarakat setempat adalah bertani (90\%), , Nelayan (5\%) dan 5\% sisanya yakni buruh, PNS dan karyawan. Mayoritas penduduk di Desa Bara bertani dan menjadi pemilik lahan. Pemilik lahan menanam beberapa jenis tanaman seperti tanaman kelapa, coklat, dan buah pisang serta beberapa jenis umbi-umbian.

Berdasarkan hasil wawancara dengan kepala desa Bara sebelum tim melaksanakan pengabdian masyarakat, masyarakat di desa tersebut membutuhkan pelatihan-pelatihan khusus pemberdayaan dalam bidang pertanian, kelautan, pendidikan lingkungan, dan pengembangan kuliner lokal bagi kaum perempuan.

Menyadari akan hal tersebut, telah diupayakan pemutaran film lingkungan dan diskusi, Focus Group Discussion (FGD) dengan seluruh alumni universitas, FGD II dengan seluruh masyarakat desa Bara untuk melihat kebutuhan sebenarnya. Direncanakan pula penyuluhan pertanian oleh Dinas Pertanian Kabupaten Buru, penyuluhan lingkungan oleh Dinas Kehutanan Kabupaten Buru yang akan dilaksanakan pada akhir November atau awal Desember. Kemudian tim telah melakukan persiapan yang dibantu oleh salah satu Dosen Jurusan Pendidikan Biologi FITK IAIN Ambon untuk 
membuat penyuluhan dan praktek pembuatan Nata de Coco bagi para kaum perempuan dan masyarakat lainnya. Tim pengabdian pun telah membawa anakan pala sebanyak 500 anakan, 350 biji pala yang akan dijadikan anakan pala. Proses pembibitan pala dilakukan oleh Tim Pengabdian Masyarakat yang akan dilanjutkan untuk pembuatan anakan dan penanamannya oleh kelompok tani dan atau masyarakat lainnya.

Sasaran kegiatan dalam pengabdian masyarakat ini adalah para kelompok tani, kelompok nelayan, aparatur desa, kaum perempuan, dan para pemuda. Kelompok tani yang ada di desa tersebut berjumlah 4 kelompok tani, para nelayan independen, satu kelompok pelajar dan mahasiswa serta para alumninya, satu kelompok aparatur pemerintahan desa, dan kelompok kaum perempuan. Masing-masing kelompok secara keseluruhan akan diberikan pendampingan tentang pendidikan lingkungan dengan cara pemutaran film dan diskusi, FGD, dan diskusi lainnya yang berkenaan dengan kebutuhan masyarakat sekitar dalam menjaga lingkungan Desa Bara tersebut. Kelompok tani dan para nelayan independen pun diberikan pendampingan dengan cara penyuluhanpenyuluhan dan praktek tentang pertanian dan kelautan. Sedangkan kaum perempuan, pada saat ini diberikan materi tentang pemanfaatan buah kelapa untuk dijadikan kuliner nata de coco serta prakteknya. Materi ini pun sebenarnya tidak hanya diikutkan oleh kaum perempuan saja akan tetapi kaum laki-laki serta para pemuda lainnya bisa mengikuti materi tersebut karena jika hal tersebut berkelanjutan maka butuh kerjasama antara kaum perempuan dan kaum laki-laki.

\section{METODE PENDAMPINGAN}

Realisasi waktu kegiatan pengabdian masyarakat dimulai sejak bulan September s/d Desember 2015. Lokasi yang menjadi tempat pengabdian masyarakat adalah di Desa Bara Kecamatan Air Buaya Kabupaten Buru Propinsi Maluku. Khalayak sasaran dalam kegiatan pendampingan ini adalah kelompok masyarakat yang terlibat secara langsung pada kegiatan pengabdian ini terdiri dari Kelompok tani, para nelayan, kelompok perempuan, dan kelompok pelajar/mahasiswa. (Daftar hadir terlampir).

Diadakannya kegiatan pendampingan masyarakat Desa Bara dalam pendidikan lingkungan melalui live-in untuk meningkatkan pengetahuan, skill, dan sikap dalam menjaga kelestarian lingkungan serta pemanfaatan penuh dalam pengelolaan hasil produksi tanaman yang mereka kelola sendiri tidak terlepas dari peran serta dari berbagai pihak yang bersedia bekerjasama dengan tim Pengabdian Masyarakat. Pihak yang menyatakan sanggup untuk membantu kelancaran pelaksanaan kegiatan tersebut antara lain:

1. Asisten III Pemerintah Propinsi Maluku

2. Dinas Pertanian Propinsi Maluku

3. Dinas Pertanian Kabupaten Buru

4. BKSDA Propinsi Maluku

BIOLOGI SEL (VOL 9 NO 2 EDISI JUL-DES 2020 ISSN 2252-858X/E-ISSN 2541-1225) PAGE 179 
Metode yang diterapkan dalam kegiatan ini dikelompokkan atas 3 cara yakni penyuluhan secara teori (baik pendidikan lingkungan maupun tanaman), pembibitan, dan penanaman pala, cengkeh, serta tanaman pekarangan. Adapun untuk kaum perempuan dan masyarakat lainnya akan diadakan penyuluhan dan praktek pembuatan nata de coco dan atau budidaya lainnya yang sesuai dengan kondisi desa tersebut.

Materi pelatihan mencakup materi pendidikan lingkungan, pembibitan tanaman pala, cengkeh, dan tanaman pekarangan lainnya serta cara penanaman tanaman disiapkan oleh fasilitator dan tim serta dibantu oleh Dinas Pertanian. Rancangan penilaian keberhasilan kegiatan pendampingan pada masyarakat di Desa Bara Kecamatan Air Buaya Kabupaten Buru Propinsi Maluku dalam pendidikan lingkungan untuk meningkatkan kesadaran dalam menjaga kelesetarian lingkungan dan memproduksi tanaman lokal sekitar akan mengacu pada strandar berikut.

1. Masyarakat yang mewakili dalam kegiatan sudah mewakili dari masyarakat yang berdomisili di Desa Bara dan sesuai dengan target.

2. Masyarakat ikut berpastisipasi aktif selama kegiatan berlangsung.

3. Pelaksanaan kegiatan sesuai dengan tujuan program

4. Kepuasan dapat dirasa dari berbagai pihak, baik pendukung kegiatan, peserta maupun tim.

\section{HASIL DAN PEMBAHASAN}

Istilah pendampingan berasal dari kata "damping" yang artinya sejajar atau setara. Pendamping adalah seorang atau kelompok orang yang berkumpul dalam sebuah lembaga yang melakukan pendampingan, dimana antara kedua belah pihak terjadi kesetaraan, kemitraan, kerjasama dan kebersamaan, tanpa ada batas golongan kelas atau status sosial yang tampak.

Prinsip dasar dari pendampingan adalah egaliter yakni kedudukan yang sama, dengan demikian hubungan antara pendamping dan kelompok masyarakat yang didampingi adalah kemitraan. Tujuan pendampingan adalah pemberdayaan atau penguatan. Pemberdayaan berarti mengembangkan kekuatan atau kemampuan (daya), potensi, sumber daya masyarakat agar mampu membela dirinya sendiri. Hal yang paling inti dari pemberdayaan adalah peningkatan kesadaran masyarakat. Jika masyarakat telah memiliki kesadaran maka ia akan memahami hak dan tanggungjawabnya dan akan berupaya untuk mempersiapkan diri dan kehidupan yang lebih baik.

Dalam pengabdian masyarakat ini, pendampingan masyarakat berkenaan dengan masyarakat yang disekelilingnya adalah hutan. Oleh karena itu pemberdayaan masyarakat untuk Desa Bara adalah upaya untuk meningkatkan kemampuan dan kemandirian masyarakat dalam mendapatkan manfaat sumberdaya hutan dan lahan secara optimal melalui pengemabangan kapasitas dan pemberian akses dalam rangka peningkatan kesejahteraan masyarakat setempat. 
Pendidikan lingkungan merupakan usaha perorangan atau kelompok untuk melestarikan dan memanfaatkan lingkungan secara bijak. Pendidikan lingkungan di Desa Bara dilakukan untuk mengintegrasikan penndidikan lingkungan kedalam tata pengelolaan lahan hutan dan kebun. Menurut Afandi (2013: 98), pendidikan merupakan wahana yang paling tepat dalam memberikan pengetahuan, keterampilan, dan sikap tentang kepedulian lingkungan kepada manusia. Dalam hal ini, tim melakukan pendidikan dengan cara berbagai penyuluhan dan diskusi serta FGD yang dilakukan berkali-kali sesuai dengan kebutuhan masyarakat.

Menurut Barlia (2008: 3), "pendidikan lingkungan hidup harus dapat mendidik individu-individu yang responsif terhadap laju perkembangan teknologi, memahami masalah-masalah di biosfer, dan berketerampilan siap guna yang produktif untuk menjaga dan mempertahankan kelestarian alam”. Masyarakat Desa Bara merespon dengan sangat positif terhadap pendidikan lingkungan yang dilaksanakan oleh Tim Pengabdian Masyarakat dan mengambil langkah-langkah kedepan dalam pengembangan pendidikan lingkungan untuk masa depan masyarakat Desa Bara yang lebih baik.

Kawasan hutan di sekitar Desa Bara termasuk pula kawasan Hutan Lindung yang diawasi dan dijaga oleh Dinas Kehutanan Kabupaten Buru Propinsi Maluku. Kaku Ghegan adalah Gunung yang berada di sebelah utara Desa Bara yang juga termasuk dalam kawasan hutan lindung. Kaku Ghegan merupakan kawasan pegunungan karst terbesar yang berada di Pulau Buru. Inipun perlu dilakukan penelitian lebih lanjut tentang kandungan gunung tersebut. Pendidikan lingkungan sangat bermanfaat dalam menambah pengetahuan, ketrampilan, dan sikap masyarakat terhadap proses pengawasan hutan lindung tersebut secara bersama-sama. Walaupun kawasan lindung di desa tersebut bukan termasuk kawasan konservasi, tetapi pemahaman tentang desa konservasi harus selalu diterapkan oleh masyarakat dalam kehidupan sehari-hari. Menurut Soemarno (2011: 1), desa konservasi adalah sebuah pendekatan model konservasi yang memberi peluang kepada masyarakat yang tinggal di sekitar kawasan konservasi untuk terlibat aktif dalam upaya pengelolaan kawasan konservasi. Dalam hal ini, masyarakat desa Bara begitu antusias walaupun kawasan mereka adalah masih kawasan hutan lindung.

Soemarno pun mengatakan bahwa model ini juga memberi peluang kepada masyarakat untuk mendapat akses yang aman untuk pemanfaatan kawasan sehingga dapat menjamin komitmen jangka panjang mereka untuk mendukung konservasi kawasan hutan. Secara umum, Konservasi Sumber Daya Alam Hayati (KSDAH) adalah pengelolaan sumberdaya alam hayati yang pemanfaatannya dilakukan secara bijaksana untuk menjamin kesinambungan persediaannya dengan tetap memelihara dan meningkatkan kualitas nilai dan keanekaragamannya.

\section{Partisipasi Masyarakat}

Masyarakat yang mengikuti kegiatan merupakan perwakilan dari seluruh masyarakat yang ada di Desa Bara. Mereka sangat berpartisipasi aktif selama kegiatan ini 
berlangsung. Hal ini dapat terlihat ketika masyarakat bersedia meluangkan waktu untuk bersama-sama dengan tim hingga kegiatan selesai. Komitmen yang mereka tunjukkan memberikan semangat bagi tim. Mereka sangat antusias dan memberikan respons positif terkait kegiatan ini.

Kegiatan diawali dengan observasi tim ke lokasi kegiatan di Desa Bara Kecamatan Air Buaya Kabupaten Buru Propinsi Maluku. Saat tiba di lokasi tim langsung bertemu dengan kepala desa dan menyampaikan maksud kedatangan tim di desa tersebut. Selanjutnya tim berkoordinasi dengan kepala desa untuk dapat bertemu dengan masyarakat dan bersama-sama menyepakati waktu yang tepat untuk pelaksanaan kegiatan sebagaimana terjadwal.

\section{Faktor Pendukung dan Kendala yang ditemukan di Lapangan}

Beberapa faktor yang mendukung tim dalam kegiatan ini adalah bersedianya masyarakat untuk bertemu dalam pertemuan pendidikan lingkungan dan tersedianya lahan yang dapat digunakan untuk menanam pala, cengkeh, dan tanaman pekarangan lainnya, koordinasi yang baik antara kepala desa dan aparatur pemerintah desa lainnya serta masyarakat sehingga kegiatan dapat terlaksana sesuai dengan target yang ditentukan. Selain faktor pendukung terdapat beberapa hal yang menjadi kendala yakni lokasi yang cukup jauh yakni dari kota Ambon menuju Desa Bara memakan waktu kurang lebih 12 jam menggunakan angkutan laut dan angkutan darat, kemudian lahan yang digunakan sangat jauh dari Desa, juga kegiatan berlangsung pada musim kemarau dan sarana air yang cukup jauh dari lokasi sehingga butuh waktu, dan tenaga untuk mengangkut air ke lokasi. Hal lainnya yakni terdapat beberapa masyarakat yang belum terlibat secara penuh disebabkan karena berhalangan.

\section{KESIMPULAN}

Berdasarkan hasil kegiatan yang telah dilakukan oleh masyarakat di Desa bara Kecamatan Air Buaya Kabupaten Buru Propinsi Maluku maka dapat disimpulkan bahwa kegiatan tersebut sangat bermaanfat bagi masyarakat setempat guna mempersiapkan mereka menjadi masyarakat sadar lingkungan dan berkarya karena memiliki pengetahuan dan keterampilan yang memadahi dan hasilnya dapat dijadikan sumber penghasilan tambahan bagi masyarakat itu sendiri guna memenuhi kebutuhan keluarga.

\section{SARAN}

Melihat potensi dan harapan yang begitu besar yang diberikan masyarakat maka ke depan kegiatan ataupun program seperti ini dapat ditingkatkan lagi modalnya sehingga dapat melibatkan banyak masrayarakat serta dilakukan untuk skala yang lebih besar dan bervariasi serta pendampingan yang rutin sehingga hasilnya akan jauh lebih baik lagi dan berguna bagi masyarakat. 


\section{DAFTAR PUSTAKA}

Budidaya

Pala.

Budidaya

Petani.

http://budidaya-

petani.blogspot.co.id/2012/08/budidaya-pala.html. Di akses tanggal 13 oktober2015

Nandang Sudrajat. Pembinaan Masyarakat Sekitar Hutan: Pengendalian Kerusakan Lingkungan Akibat Aktivitas Penambangan dari Ijin yang dikeluarkan Daerah. Diakses tanggal 13 Oktober 2015

Rifki Afandi. 2013. Integrasi Pendidikan Lingkungan Hidup melalui Pembelajaran IPS di Sekolah Dasar sebagai Alternatif Menciptakan Sekolah Hijau. Pedagogia, Vol. 2, No. 1, Februari 2013: halaman 98-108

Soemarno. 2011. Model Desa Konservasi. pslp-ppsub-2011. Diakses tanggal 10 Oktober 2015

Wahyu Surakusumah. 2009. Model Uji Coba Sekolah Berwawasan Lingkungan. https://wahyusurakusumah.wordpress.com/2009/08/13/konsep-pendidikanlingkungan-hidup/. Diakses tanggal 10 Oktober 2015 